\title{
EQUITY'S JURISDICTION TO RELIEVE AGAINST FORFEITURE OF LEASES - AN HISTORICAL PERSPECTIVE
}

\author{
Mark Pawlowski *
}

\begin{abstract}
ABSRACT
This article seeks to trace the evolution of equity's jurisdiction to relieve against the forfeiture of leases from the early $17^{\text {th }}$ century cases through to the present day in the United Kingdom jurisdiction. Although the celebrated case of Sanders $v$ Pope, ${ }^{1}$ decided in 1806, marked a trend towards a more flexible (discretionary) approach to equitable relief, this was to be short lived following Lord Eldon's judgment in Hill v Barclay ${ }^{2}$ in 1811 declining to grant relief against forfeiture of a lease for a wilful breach of covenant not involving the failure to pay rent even where the same was capable of adequate compensation. This remained the position until 1973, when the House of Lords in Shiloh Spinners Ltd v Harding ${ }^{3}$ took the opportunity to review the whole question of the scope of equity's jurisdiction to relieve against forfeitures. What emerged was a principled approach to the grant of equitable relief which was not limited to the two orthodox heads of relief: (a) where the right to forfeit was inserted by way of security for the payment of rent and (b) where the breach had been occasioned by fraud, accident, mistake or surprise. The Shiloh ruling paved the way for the granting of relief for breaches of other covenants in the same way as that in the case of rent, namely, to prevent a forfeiture where the landlord may be adequately compensated and receive proper undertakings as to future performance, so that the forfeiture clause is merely security to achieve these results.

The article also examines the current scope of equity's jurisdiction to relieve against forfeiture given that the court's statutory power to grant relief has been gradually extended in the landlord and tenant context from the single case of non-payment of rent till it has reached its present dimensions of a broadly based jurisdiction to relieve against virtually all forms of default by
\end{abstract}

* LL.B (Hons), BCL (Oxon), ACIArb, SFHEA, Barrister, Professor of Property Law, School of Law, University of Greenwich.

1 (1806) 12 Ves Jun 283; 33 ER 108.

2 (1811) 18 Ves Jun 56; 34 ER 238.

${ }^{3}$ [1973] AC 691. 
the tenant, sub-tenant or mortgagee. What emerges is a more limited, but no less significant, equitable power to grant relief outside the court's statutory jurisdiction. In jurisprudential terms, it is argued, equity's ability to prevent the unconscionable exercise of legal rights remains at the heart of our common law tradition.

\section{INTRODUCTION}

To the ordinary person, the term "equity" connotes justice and fairness reflecting some universally accepted concept of right and wrong. To the lawyer, however, brought up in the common law tradition, it has been associated with judicial decision-making to ensure that justice is done between the parties to a dispute. To this extent, the term has acquired a specific and technical meaning, namely, that body of law which evolved historically through the Court of Chancery to mitigate the rigours and deficiencies of the early common law. In the words of Lord Ellesmere in the Earl of Oxford's Case,4 heard in 1615:

“[Men's] actions are so diverse and infinite that it is impossible to make any general law which may aptly meet with every particular and not fail in some circumstances. The office of the Chancellor is to correct men's consciences for frauds, breaches of trust, wrongs and oppression of what nature so ever they be, and to soften and mollify the extremity of the law."

Undoubtedly, the greatest influence of equity has been in the development of English land law, in particular, the granting of relief ${ }^{5}$ against the forfeiture of leases. The landlord's right to forfeit (i.e., terminate) a lease for breach of any tenant's covenant or condition in the lease, regardless of the gravity or seriousness of the breach, was seen as one of the common law's harshest of remedies which had the potential to cause grave injustice to the defaulting tenant. It is not surprising, therefore, that from earliest times, the Court of Chancery recognised an equitable jurisdiction to relieve against forfeiture of leases where the landlord could be put back into the same position as if the tenant's obligation in question had not been broken. ${ }^{6}$ The underlying principle

${ }^{4}$ (1615) 1 Rep Ch 1, 6.

${ }^{5}$ In the sense of allowing the tenant to retain his leasehold term.

${ }^{6}$ See generally, White and Tudor's Leading Cases in Equity, ( $9^{\text {th }}$ ed, 1928), Vol. 2, pp 222-227, 235-236 and 239-241; Woodfall's Law of Landlord and Tenant, (21 $\left.{ }^{\text {st }} \mathrm{ed}\right)$, pp 405-407 and Platt on Leases, Vol 2, pp 485 et seq. 
determining relief was whether the landlord could be adequately compensated for his loss occasioned by the tenant's breach.

Whilst, however, there was no difficulty in compensating a landlord for a tenant's failure to pay rent in due time by simply permitting the tenant to tender late payment with interest and costs, ${ }^{7}$ other breaches did not readily permit the placing of the landlord in the same position he would have been if no breach had occurred. For this reason, as we shall see, no relief could be given in respect of a tenant's breach of covenant not to assign or sub-let, to insure or to carry out repairs to the demised premises. ${ }^{8}$ In each of these cases, the courts of equity declined relief to the tenant because it was not possible to quantify the extent of the landlord's loss or injury occasioned by the breach. Although some attempt was made judicially to widen equity's jurisdiction in the early $19^{\text {th }}$ century, it was not until 1973 that the House of Lords confirmed that this inherent jurisdiction extended beyond the granting of relief for nonpayment of rent to cover wilful breaches of other forms of covenant.

The long history surrounding the evolution of equity's willingness to grant relief against forfeiture of leases is a fascinating story with all the twists and turns of a romantic novel. We begin with the earliest cases decided in the $17^{\text {th }}$ century where the notion of relief based upon a compensatory principle was first developed.

\section{RELIEF UPON MAKING MEASURABLE COMPENSATION}

The earliest reported case appears to be Cage $v$ Russell, ${ }^{9}$ decided in 1681, where a testatrix left lands to the executors of her will to pay the sum of $£ 500$ out of them to her son when he should reach the age of 21 . The devise was made subject to the proviso that, if the father's son failed to give a release for the lands, the sum of $£ 500$ was to be forfeited to the executors. The father was subsequently willing to grant the release and the court decreed payment of the $£ 500$ to the son stating that:

\footnotetext{
7 It was assumed that, if the money was paid with interest and costs, this was a sufficient indemnity to the landlord. Yet, in a number of cases, no doubt, considerable inconvenience was suffered by the landlord not having the money paid at the due time. Any such inconvenience, however, appears to have been disregarded by equity in granting relief. This was recognised by Lord Eldon in Reynolds $v$ Pitt (1812) 19 Ves 134, 34 ER 468, where he said: "The failure of the payment at the time may be attended with mischievous consequences, that never can be cured in a rational sense by subsequent payment with the addition of interest”.

8 See, Eden, A Treatise on the Law of Injunctions, (1821), p 26 and Comyn, Treatise on the Law of Landlord and Tenant, (1821), pp 494-495.

${ }^{9}$ (1681) 2 Vent 352; 86 ER 481.
} 


\section{EQUITY'S JURISDICTION TO RELIEVE AGAINST FORFEITURE OF LEASES - AN HISTORICAL PERSPECTIVE}

"It was the standing rule of the Court, that a forfeiture should not bind where a thing may be done afterwards, or any compensation made for it. As when the condition was to pay money or the like.”

An early formulation of this principle is to be found in the judgment of Lord Nottingham LC in Popham $v$ Bampfeild: ${ }^{10}$ "when the court can in any case compensate the party in damages for the non-precise performance of the condition, there it is just and equitable to relieve”. Another $17^{\text {th }}$ century case is Webber $v$ Smith, ${ }^{11}$ where the landlord forfeited the tenant's interest in a number of houses on the ground of the latter's failure to pay rent and repair the houses in accordance with the terms of the lease. The tenant had sub-let the premises and the sub-tenants were granted relief from forfeiture upon payment of the arrears and repair of all the houses.

These early cases paved the way for the emergence of the principle that equity only had jurisdiction to relieve against a forfeiture where the object of the forfeiture clause was to secure payment of a definite sum of money. In Grimstone v Bruce, ${ }^{12}$ for example, certain lands were devised upon condition that the devisee paid the testator's debts and legacies. One such legacy involved a payment of $£ 30,000$ to the testator's grand-daughter to be paid (initially) in instalments of $£ 1,000$ per year. The condition was broken but Lord Chancellor Cowper granted relief by allowing late compliance with the condition and awarding payment of interest on each instalment from the time each fell due for payment together with the costs of the action.

It was not, however, until 1721 that the principle was clearly formulated by Lord Macclesfield in one of the leading cases of the period. In Peachy $v$ Duke of Somerset, ${ }^{13}$ the owner of a copyhold estate had entered into various leases contrary to the custom of the manor and without licence of the lord. He sought to be relieved from the forfeiture of his estate by offering to make recompense for the breach but his Lordship refused relief, stating: ${ }^{14}$

"The true ground of relief against penalties is from the original intent of the case, where the penalty is designed only to secure money, and the court gives him all he expected or deserved: but it is quite otherwise in the present case. These penalties or forfeitures were never intended by way of compensation, for there can be none."

10 (1682) 1 Vern 79, at 83; 23 ER 325, at 326.

11 (1689) 2 Vern 103; 23 ER 676.

12 (1707) 2 Vern 594; 23 ER 986.

13 (1721) 1 Stra 447; 93 ER 626.

${ }^{14}$ Ibid, 453; 630. 
This narrow view of the scope of equity's jurisdiction was also favoured in the subsequent case of Descarlett $v$ Dennett, ${ }^{15}$ where Sir Joseph Jekyll MR refused to grant relief on the basis that: "the Court of Chancery cannot relieve the non-performance of a covenant or condition, the prejudice in breach of which cannot be estimated by damages". Two years later, a similar conclusion was reached in Wafer $v$ Mocatto, ${ }^{16}$ where the claimant, the tenant of certain houses in London, assigned the same in breach of a covenant in the lease not to assign without the prior consent of the landlord. Lord Macclesfield took the opportunity to re-iterate the view he adopted in the Peachy case by saying that: "this Court never relieves but in such cases where it can give some compensation in damages and where there is some rule to be the measure of damages, to avoid being arbitrary". In this case, the court proceeded on the basis that the landlord could not be returned to his position prior to the tenant's breach because, where there was an assignee without licence, the court could not ascertain the compensation which should be awarded to the landlord for having a new tenant forced upon him.

A number of early cases also sought to restrict equitable relief to cases not involving wilful neglect or misconduct on the part of the defaulting party. In Eaton $v$ Lyon, ${ }^{17}$ for example, the tenant failed to serve a formal notice of exercise of an option to renew a lease within a specified time. In refusing the tenant relief, Lord Alvanley said:

"At law a covenant must be strictly and substantially performed according to the true intent and meaning of the parties, so far as circumstances will admit; but if by unavoidable accident, if by fraud, by surprise, or ignorance not wilful default, parties may have been prevented from executing it literally, a Court of Equity will interfere; and upon compensation being made, the party having done everything in his power and being prevented by the means I have alluded to, will give relief." 18

This was not, however, the approach taken by Lord Erskine eight years later in the celebrated case of Sanders $v$ Pope,${ }^{19}$ involving a lease of a public house which contained a covenant on the part of the tenants to spend the sum of $£ 200$ in improving and repairing the premises before the end of the first

${ }^{15}$ (1722) 9 Mod 22; 88 ER 290.

${ }^{16}$ (1724) 9 Mod 12; 88 ER 348. See also, Rose v Rose (1756) Amb 331; 27 ER 222.

${ }^{17}$ (1798) 3 Ves Jun 691; 30 ER 1223.

${ }^{18}$ Ibid, 692-693; 1224.

${ }^{19}$ Above $n 1$. 


\section{EQUITY'S JURISDICTION TO RELIEVE AGAINST FORFEITURE OF LEASES - AN HISTORICAL PERSPECTIVE}

five years of the term. The tenants failed to carry out the repairs and the landlord forfeited the lease. The issue before the court was whether the tenants were entitled to relief in equity upon them laying out the sum of $£ 200$ in repairs or otherwise making compensation to the landlord for their breach. In granting relief, Lord Erskine, in a classic judgment, said: ${ }^{20}$

"There is no branch of the jurisdiction of this Court more delicate than that which goes to restrain the exercise of a legal right. That jurisdiction rests only upon this principle; that one party is taking advantage of a forfeiture; and as a rigid exercise of the legal right would produce a hardship, a great loss and injury on the one hand arising from the going to the full extent of the right, while on the other the party may have the full benefit of the contract, as originally framed, the Court will interfere; where a clear mode of compensation can be discovered.”

In the instant case, the covenant provided for the expenditure of a specific sum of money (£200) on the property over a period of five years and, consequently, the difficulty of seeking to make an award of general damages to compensate for the breach did not arise. However, it is significant that the court was not prepared to draw any distinction between expenditure of a specified sum on repairs within a prescribed period and payment of arrears of rent. In this connection, Lord Erskine observed: ${ }^{21}$ if it is a subject admitting of certain calculation, though not a specific sum of money or rent, relief may be given.” His Lordship also had occasion to refer to the judgment of Lord Alvanley in Eaton $v$ Lyon (where, it will be recalled, it was sought to confine equity's jurisdiction to cases where there was no wilful neglect or misconduct on the part of the party in breach) and said: ${ }^{22}$

"If the covenant is broken with the consciousness that it is broken, that is, if it is wilful, not by surprise, accident or ignorance, still if it is a case, where full compensation can be made, these authorities ${ }^{23}$ say, not that it is imperative upon the Court to grant relief, but that there is a discretion.”

\footnotetext{
${ }^{20}$ Ibid, 289; 110.

${ }^{21}$ Ibid, 290; 111.

22 Ibid, 293; 112.

${ }^{23}$ See, Cage v Russell (1681) 2 Vent 352; 86 ER 481; Northcote v Duke (1765) Amb 511; 27 ER 330; Hack v Leonard (1724) 9 Mod 90; 88 ER 335; Wafer v Mocatto (1724) 9 Mod 12; 88 ER 348 and Eaton v Lyon (1798) 3 Ves Jun 691; 30 ER 1223.
} 
A year later, Lord Erskine re-iterated this view in Davis $v$ West,${ }^{24}$ a case involving the forfeiture of a lease for non-payment of rent. The Lord Chancellor said:

“. . . where the covenants are broken, and there is no fraud, and the party is capable of giving complete compensation, it is the province of a Court of Equity to interfere, and give relief against the forfeiture for breach of other covenants, as well as those for payment of rent." 25

There is no doubt that the case of Sanders $v$ Pope marked a turning point in the evolution of equity's jurisdiction to grant relief against forfeitures. It paved the way for the acceptance by equity of a more robust attitude to do justice between the parties irrespective of the nature of the covenant broken and the wilfulness of the breach, provided only that the interests of the injured party could be adequately protected by an appropriate form of order. Where, therefore, strict reliance on the forfeiture would produce an injustice to the party in breach, equity had a discretion to intervene so long as measurable compensation could be made to the injured party. This broad approach to equitable relief was, however, to be short lived for in 1811 Lord Eldon, in the landmark case of Hill $v$ Barclay ${ }^{26}$ declined to grant relief against forfeiture of a lease for a wilful breach of covenant not involving the failure to pay rent even where the same was capable of adequate compensation.

\section{NO RELIEF FOR WILFUL BREACHES}

In Hill $v$ Barclay, ${ }^{27}$ a covenant in the lease provided inter alia that, if the tenants did not, within a specified time period, spend $£ 150$ on repairs to the demised premises or otherwise did not repair the premises within three months of being notified to do so by the landlord, the latter was entitled to reenter the premises and forfeit the lease. The tenants failed to comply with the landlord's notice within the time period stipulated but, nevertheless, began the works following the landlord's action for ejectment. They then sought an injunction to restrain the landlord's action on the ground that the works would be completed and the premises put in a complete state of repair. Lord Eldon

24 (1806) 12 Ves 475; 33 ER 180.

${ }^{25}$ Ibid, 476; 180.

${ }^{26}$ Above, n2.

${ }^{27}$ See also, 16 Ves Jun 402; 33 ER 1037, where Lord Eldon in an earlier motion in the case involving the tenant's claim for an injunction to restrain the landlord's ejectment said: “ . . . a Court of Equity would not relieve against a breach of a general covenant to do repairs". 


\section{EQUITY'S JURISDICTION TO RELIEVE AGAINST FORFEITURE OF LEASES - AN HISTORICAL PERSPECTIVE}

distinguished the earlier case of Sanders $v$ Pope on the basis that it involved the laying out of a specific sum of money by the tenant towards the repair of the demised property and that the landlord had made no specific demand on the tenant to repair the premises prior to commencing his action for ejectment.

In referring to the earlier cases, his Lordship observed that a "very material consideration" which had been overlooked was that equitable relief could not be given in circumstances where the breach of the covenant was wilful. Accordingly, on the basis that the breach in the case before him was both wilful and incapable of giving rise to an accurate estimate in damages, he dismissed the tenant's motion for an injunction to restrain possession. His decision was, no doubt, influenced by a strong desire not to interfere with the contract made between the parties and, in particular, the landlord's unfettered legal right to re-enter for breach of covenant in the absence of exceptional circumstances. A similar approach was adopted in Rolfe $v$ Harris,${ }^{28}$ where the tenant had neglected to insure the premises in breach of covenant. In refusing relief, Sir T. Plumer VC said:

“... where the Court will relieve, the omission and consequent failure, must be the effect of inevitable accident, and the injury or inconvenience arising from it must be capable of compensation; but where the transgression is wilful, or the compensation impracticable, the Court will refuse to interfere.”

A number of subsequent cases followed this reasoning. In Reynolds $v$ Pitt, ${ }^{29}$ the tenant neglected to renew the insurance during a period of two years, but effected the policy on the very same day that the landlord brought an action for ejectment. Lord Eldon, after an extensive review of the earlier authorities, concluded that equity had no jurisdiction to relieve against the wilful breach of a covenant to insure. The case proceeded on the basis that the risk which the landlord had incurred during the period when no insurance was in force was something which could not be the subject of compensation.

A leading case of the time (and which merits detailed analysis) is Bracebridge $v$ Buckley, ${ }^{30}$ where the Court of Exchequer refused to grant equitable relief to a tenant who was in breach of a covenant to lay out a sum of $£ 1,000$ to repair the demised premises within a stipulated time on the

28 (1811) 2 Pri 202; 145 ER 68.

29 (1812) 19 Ves 134; 34 ER 468. See also, Lovat $v$ Lord Ranelagh (1814) 3 Ves \& Bea 24; 35 ER 388.

30 (1816) 2 Pri 200; 146 ER 68. See also, White $v$ Warner (1817) 2 Mer 459; 35 ER 1016; Green v Bridges (1830) 4 Sim 96; 58 ER 37 and Shearman v McGregor (1853) 11 hare 106; 68 ER 1206. 
ground that it had no effective means of ascertaining precisely what compensation the landlord was entitled to in these circumstances. Moreover, relief was denied notwithstanding the fact that no damage had been sustained by the delay in carrying out the repair works and that the premises would be put into as good (or even better) condition than they would have been if the covenant had been punctually performed. Counsel for the tenant relied primarily on Sanders $v$ Pope in support of the contention that equity had jurisdiction to relieve in cases where the covenant provided for the expenditure of a specific sum of money. He also referred to a number of matters which he argued made it just and equitable that relief should be granted. First, the tenant was willing to submit to any terms the court thought fit to impose even if this meant placing the landlord in a better position than he would have been if the covenant had been strictly performed in accordance with the terms of the lease. Secondly, the tenant had been lulled into a false sense of security since the landlord had permitted him to continue in undisturbed possession of the premises for two years after the breach of covenant had occurred. Thirdly, it was argued that, despite the specific time limit for carrying out the repairs under the lease, the parties had, in fact, understood that the tenant was to take his own time to proceed with the repairs. It was submitted, therefore, that the tenant's breach could not be characterised as a wilful neglect to perform the covenant. Moreover, the landlord had given no prior notice of his intention to re-enter for the breach. As to the court's difficulty in securing that precise compensation was made to the landlord, it was suggested on behalf of the tenant that the court could direct an inquiry as to what sum would be necessary to put the premises into the same state of repair as they would have been if the money had been applied according to the terms of the lease.

None of these arguments found favour with the majority of the court, but a strong dissenting judgment was given by Baron Wood who concluded that the tenant should be relieved on laying out the $£ 1,000$ towards the repairs and paying all the landlord's costs of the action. In his view, equity could grant relief wherever it was possible to award sufficient compensation in damages to the injured party: "equity will relieve in almost all cases of forfeiture, if they can put the parties in as good a condition". ${ }^{31}$ One exception to this broad principle was the breach of a covenant not to assign or underlet where no damage could be ascertained "because the tenant, though he might be perfectly solvent, may not be, in other respects, such a man as the landlord would choose". ${ }^{32}$ For the same reason, the breach of a covenant to insure

\footnotetext{
${ }^{31}$ Ibid, 221; 76.

32 Ibid, 221; 76.
} 


\section{EQUITY'S JURISDICTION TO RELIEVE AGAINST FORFEITURE OF LEASES - AN HISTORICAL PERSPECTIVE}

could not be the subject of relief because the injury suffered by the landlord (i.e., the risk which the landlord would inevitably incur whilst the premises remained uninsured) was not susceptible of measurement by an award of damages. In the context of a tenant's neglect to repair, however, the learned Judge considered that the various objections to the practicability of granting relief were ill-founded: "the course of reference to the Master is an answer to all those difficulties". ${ }^{33}$ In adopting, therefore, an expansive approach to equity’s jurisdiction, he concluded:

"All the cases must depend on the tenant, and be governed by their own particular circumstances. Where, indeed, he has been guilty of wilful waste, or even presumptive waste, relief might properly be refused: but not for a mere want of repair, which, at the time of the application to be relieved, can be effectually supplied.” 34

The case of Hannan $v$ The South London Waterworks Company ${ }^{35}$ (decided in the same year) is also of interest. Here, Lord Eldon, whilst reaffirming the principle that, in general, the court would not relieve against the breach of a covenant to repair, had occasion to grant equitable relief (in the form of an injunction restraining an action for ejectment) in favour of a tenant who was in breach of his covenant to repair the premises. The facts of this case were, however, considered by the Lord Chancellor to be exceptional in so far as the tenant had contracted to deliver up possession of the premises to a third party, who in turn intended to demolish the premises pursuant to the latter's statutory powers. In this case at least, the court felt no difficulty in granting equitable relief upon terms which would compel the tenant to perform his obligations under the repairing covenant and make appropriate compensation to the landlords in the event of a proven diminution in value of their reversionary interest occasioned by the breach. Inevitably, any such compensation would fall to be measured by means of an inquiry as to the market value of the landlord's interest in the property in its unrepaired state and its condition on the assumption that the tenant had complied with his obligations under the lease. This, therefore, clearly marks a departure from the earlier authorities which denied relief for the very reason that the injury suffered by the landlord was not the subject of measurable compensation in cases involving disrepair.

Despite this apparent relaxation of the Hill $v$ Barclay principle, the courts, nevertheless, continued to adopt a restrictive approach to the scope of equity

${ }^{33}$ Ibid, 223-224;77.

${ }^{34}$ Ibid, 225; 77.

35 (1816) 2 Mer 65; 35 ER 863. 
jurisdiction to grant relief. A good example is Harries $v$ Bryant, ${ }^{36}$ where Sir John Leach MR extended the meaning of wilful breaches to include an omission occurring through negligence as a result of a failure to act with reasonable diligence prudence. He said: ${ }^{37}$ "Ignorance is considered to be wilful, where a person neglects the means of information, which ordinary prudence would suggest; and accident is not unavoidable, which reasonable diligence might have prevented."

Thus, in Bargent $v$ Thompson, ${ }^{38}$ for example, the court granted the tenant relief from forfeiture for non-repair of the premises on the exceptional ground that the remedial work had been delayed because of poor weather conditions. ${ }^{39}$

\section{SUSPENSION OF RIGHTS}

In the celebrated case of Hughes $v$ Metropolitan Railway $\mathrm{Co},{ }^{40}$ the House of Lords, whilst re-affirming what had by then become the established view that "equity had no general power to relieve against forfeiture by way of mercy or by way merely of saving property from forfeiture, ${ }^{41}$ held that equity could intervene to grant relief in exceptional circumstances where the party in default had been misled by the other party's conduct into believing that the latter's strict legal rights had been abandoned or suspended for a time.

In Hughes, the landlords had served a notice on the tenant to repair various houses forming the subject-matter of the lease within a period of six months expiring on April 22, 1875. Upon service of this notice, the tenant

${ }^{36}$ (1827) 4 Russ 89; 38 ER 738. See also, Gregory v Wilson (1852) 9 Hare 683; 68 ER 687, where Sir G.J. Turner VC said: "Where a man, who knows that he is charged with a legal obligation, neglects to perform it, his neglect to do so must be deemed to be wilful and, if he persists in it, to be obstinate", and Elliott $v$ Turner (1843) 13 Sim 477; 60 ER 185, where Sir Lancelot Shadwell VC suggested that the word "wilful" meant "spontaneous" so that, if the neglect or default arose from a voluntary act and not from the pressure of external circumstances over which the party in default had no control, the neglect or default fell to be classified as wilful. In his view, mere forgetfulness could amount to wilful neglect.

${ }^{37}$ Ibid, 91; 739.

38 (1864) 4 Giff 473; 66 ER 792. See also, Bamford v Creasy (1862) 3 Giff 675; 66 ER 579.

${ }^{39}$ In Hill $v$ Barclay, Lord Eldon himself observed: "I do not mean to apply these observations to cases of accident and surprise; the effect of the weather, . . . or permissive want of repair, the landlord standing by and looking on" (emphasis added): (1811) Ves Jun 56, 62; 34 ER 238, 240.

${ }^{40}$ (1877) 2 App Cas 439. See also, Bruner v Moore [1904] 1 Ch 305.

${ }^{41}$ Ibid, at 448, per Lord Cairns (LC). 


\section{EQUITY'S JURISDICTION TO RELIEVE AGAINST FORFEITURE OF LEASES - AN HISTORICAL PERSPECTIVE}

made an offer to sell his interest in the premises to the landlords and various negotiations ensued culminating in a letter from the landlords (written on December 31, 1874) requiring a modification of the tenant's proposals. No further communication was made between the parties until April 1875 when the landlords wrote stating inter alia that the tenant had had ample time to complete the repairs since December 1874 when negotiations had broken off. Shortly after the expiry of the repair notice, the landlords brought an action for ejectment. The House of Lords held that the tenant was entitled to be relieved from the forfeiture on the basis that the negotiations had the effect of suspending the notice and that this suspension did not come to an end until December 31, 1874. Accordingly, till that time, the operation of the notice had been waived by the landlords so that no part of that time could be counted against the tenant in calculating the six months' notice to repair.

\section{FRAUD, ACCIDENT, SURPRISE AND MISTAKE}

The reluctance of the courts to expand the boundaries of equity's jurisdiction is also amply illustrated by the Court of Appeal decision in Barrow v Isaacs. ${ }^{42}$ In this case, the tenants had underlet part of the demised premises without the prior consent of the landlord in breach of a covenant in the lease. The underletting had, in fact, been prepared by their solicitors who had omitted to look at the head lease and forgot that it contained the covenant not to underlet without consent. The undertenants were respectable and responsible persons and no injury had been suffered by the landlord by the grant of the underletting. Moreover, the landlord would have had no valid objection to the underletting had consent, in fact, been asked. Nevertheless, the Court of Appeal felt constrained to hold that the landlord was entitled to succeed in his action for possession on the ground that the omission to ask the landlord's consent was not a mistake falling within the recognised heads of equity's jurisdiction to grant relief. Lord Esher MR put the matter this way: ${ }^{43}$

"Equity, it is said, will relieve against fraud, accident or mistake; and I think you must add that equity will only relieve when there can be complete compensation, or where there is no injury which requires compensation. Under which head is this case brought? It is obvious that it is not fraud. This is not to be attributed to either of the parties. It is not accident, because it is the result of something which was done on behalf of one of the parties. Is it a mistake? . . . if you treat mistake

\footnotetext{
42 [1891] 1 QB 417. See also, Ellis v Allen [1914] 1 Ch 904, 909; Eastern Telegraph Co Ltd v Dent [1899] 1 QB 835 and Atkin v Rose [1923] 1 Ch 522, 539.

${ }^{43}$ Ibid, 420.
} 
in its ordinary sense in the English language, is mere forgetfulness mistake? Can you, in English, say, 'I forgot', and is this the same thing as saying 'I was mistaken?' I think not.”

It is noteworthy, however, that the learned Judge also concluded that, had the case been one of mistake, he would have granted equitable relief notwithstanding the fact that the tenants' agent had acted negligently in failing to observe the terms of the lease. Kay LJ, ${ }^{44}$ on the other hand, in refusing equitable relief, felt no difficulty in holding the tenants responsible for the carelessness of their solicitors. In a brief historical analysis of equity's jurisdiction to grant relief, ${ }^{45}$ he had cause to observe: ${ }^{46}$

"At first there seems to have been some hesitation whether this relief might not be extended to other cases of forfeiture for breach of covenants such as to repair, to insure, and the like, where compensation could be made; but it was soon recognised that there would be great difficulty in estimating the proper amount of compensation; and, since the decision of Lord Eldon in Hill $v$ Barclay, it has always been held that equity would not relieve, merely on the ground that it could give compensation, upon breach of any covenant in a lease except the covenant for payment of rent. But of course this left unaffected the undoubted jurisdiction to relieve in case of breach occasioned by fraud, accident, surprise or mistake.”

Despite his obvious reluctance to interfere with well-established principles, there is a significant recognition in Kay LJ's judgment that the court's refusal to extend the limits of equity's jurisdiction to relieve against forfeitures had produced anomalous and harsh results. He observed:

"[There] ensued a long period in which equity seems to have refused relief in cases of breach of any other covenants in a lease. Very hard cases occurred, in which unconscionable landlords insisted on their legal rights. Especially hard were these forfeitures for breach of the covenant to insure where no damage had ensued . .." 47

\footnotetext{
${ }^{44}$ With whose judgment Lopes LJ agreed.

45 See also, Howard v Fanshawe \{1895] 2 Ch 581, 586-589, per Stirling J and In Re Dixon, Heynes v Dixon [1900] 2 Ch 561, per Rigby LJ.

${ }^{46}$ [1891] 1 QB 417, 425.

47 Ibid, 429.
} 


\section{EQUITY'S JURISDICTION TO RELIEVE AGAINST FORFEITURE OF LEASES - AN HISTORICAL PERSPECTIVE}

The decision in Barrow was applied in Eastern Telegraph Company Ltd $v$ Dent ${ }^{48}$ where thoughtlessness on the part of the tenant or failure on his part to realise the gravity of a breach of covenant not to underlet without the landlord's consent were urged as grounds for relief against forfeiture. The argument was, however, firmly rejected by the Court of Appeal as having no foundation in principle or authority. ${ }^{49}$ The Barrow ruling was also referred to by Parker $\mathrm{J}$ in Matthew $v$ Smallwood, ${ }^{50}$ where the learned judge said: “ . . .carelessness on the part of the person claiming relief could not be considered in a Court of Equity to be a mistake or accident of a nature which could afford a ground for relief.” 51

\section{A DISCRETIONARY APPROACH TO RELIEF}

It will be evident from the foregoing review of the case law that equity's jurisdiction to relieve from forfeiture of leases was limited to essentially two specific heads of relief, namely, (a) where the right to forfeit was inserted by way of security for the payment of a specific sum of money (such as rent) and (b) where the breach had been occasioned by fraud, accident, mistake or surprise.

The emergence of this limited jurisdiction was, of course, largely attributable to the acceptance by the courts of the restrictive approach adopted by Lord Eldon in Hill $v$ Barclay as opposed to the more liberal and expansive view promulgated by Lord Erskine in Sanders $v$ Pope. At the heart of this dichotomy lay the court's inherent inability to compensate the injured party for any loss occasioned by the breach by means of an appropriate award of damages. It was, therefore, this inherent (procedural) disability of the Court of Chancery which precluded the development of a coherent set of equitable principles for the relief of forfeiture under English law. Because of this disability, the jurisdiction of equity was inevitably confined to very narrow limits where either the injured party could be compensated by payment of the specific money owed with interest and costs or where (because of his conduct) it would be manifestly unjust to permit a strict performance of his legal rights. Coupled with this, however, was also the acceptance of Lord Eldon's view (in

\footnotetext{
48 [1989] 1 QB 835.

${ }^{49}$ Where, however, the breach was occasioned by a bona fide belief, induced by the landlords' agents that the landlord had expressly consented to an underletting (as opposed to a mere mistake committed on the part of the tenant and his advisers) relief was granted: Upjohn v MacFarlane [1922] 2 Ch 256.

50 [1910] 1 Ch 777. See also, WG Clark (Properties) Ltd v Dupre Properties Ltd [1992] 1 All ER 596, 608.

51 Ibid, 792.
} 
preference to that of Lord Erskine) that equity would not relieve against a wilful breach of covenant. In this connection, the "wilfulness" of the breach came to be regarded as a matter that went to the court's jurisdiction whether or not to grant relief and not merely as a factor that fell to be weighed (together with other factors) in exercising its discretion whether or not to relieve in a particular case.

The foregoing remained the position ${ }^{52}$ until 1973, when the House of Lords took the opportunity to review the whole question of the scope of equity's jurisdiction to relieve against forfeiture of property in the landmark case of Shiloh Spinners Ltd v Harding. ${ }^{53}$ The leading speech was given by Lord Wilberforce, who restated the basis for equitable relief in these terms:

“. . . we should affirm the right of courts of equity in appropriate and limited cases to relieve against forfeiture for breach of covenant or condition where the primary object of the bargain is to secure a stated result which can effectively be attained when the matter comes before the court, and where the forfeiture provision is added by way of security for the production of that result. The word 'appropriate' involves consideration of the conduct of the applicant for relief, in particular whether his default was wilful, of the gravity of the breaches, and of the disparity between the value of the property of which forfeiture is claimed as compared with the damage caused by the breach.” (Emphasis added).

It is evident from this passage that Lord Wilberforce was not prepared to limit equity's jurisdiction to the two classical heads of relief referred to earlier. In his view, the policy of the law in granting the right to apply for relief from forfeiture for breaches of other covenants was the same as that in the case of rent, namely, to prevent a forfeiture where the landlord may be adequately compensated and receive proper undertakings as to future performance, so that the forfeiture clause is merely security to achieve these results.

As to the question whether Lord Eldon's view in Hill $v$ Barclay remained good law in relation to covenants to repair and similar covenants concerning the condition of the property (other than those now specifically dealt with by statute), he said:

${ }^{52}$ Lord Simon of Glaisdale in Shiloh Spinners Ltd v Harding [1973] AC 691, 707, refers to the "trail from Hill $v$ Barclay" as leading into a "juristic desert" and as demonstrating an "abnegation of equity".

${ }^{53}$ Above n3. 
“Lord Eldon LC's decision was in fact based partly on the circumstance that he was concerned with a wilful default and partly on the impossibility of speculating whether the later doing of the repairs would compensate the landlord; such considerations remain relevant.”

What is evident from this passage is that matters relating to the wilfulness of the breach and the adequacy or otherwise of compensation were now to be considered as mere factors influencing the court's discretion whether or not to grant relief in a particular case. Indeed, since the power of re-entry in Shiloh was, clearly, inserted with the intention of securing enforcement of the various covenants in the assignment, Lord Wilberforce had no difficulty in holding that the court had the requisite equitable jurisdiction to grant relief. However, as a matter of discretion, he concluded that the court ought not, in the circumstances, to grant relief to the respondent. Having examined all the evidence available to the trial judge, his Lordship concluded that the case was not one suitable for relief because of the respondent's clear and wilful braches of the covenants and his inability to make good the consequences of his default.

\section{CURRENT SCOPE OF EQUITY'S JURISDICTION}

There have been a number of cases decided since Shiloh which have raised the question whether the equitable jurisdiction to relieve from forfeiture of a lease has survived the relevant legislation giving the statutory right to such relief or whether such legislation has, in effect, impliedly extinguished the inherent jurisdiction in relation to leases.

In one group of cases, an inherent equitable jurisdiction to grant relief was upheld in circumstances where the condition for obtaining relief under the relevant statute did not apply. In Ladup Ltd v Williams \& Glyn's Bank plc, ${ }^{54}$ the claimant recovered judgment for a sum of $£ 43,000$ in an action against the tenant of a residential flat and, in order to enforce the judgment, obtained a charging order in respect of the tenant's lease of the flat. Subsequently, the landlord brought proceedings against the tenant for forfeiture of the lease for non-payment of rent and obtained possession of the flat. The claimant creditor then sought relief from forfeiture as being a person interested in the lease by virtue of the charging order. Warner $J$ held that the court was entitled, in the exercise of its inherent equitable jurisdiction, to grant relief to an equitable charge who had no interest in the lease entitling him to possession of the demised premises. In his view, there was no fetter on the jurisdiction of a court of equity to relieve against forfeiture where the object of the right to

${ }^{54}$ [1985] 2 All ER 577. 
forfeit was essentially to secure payment of a sum of money as in the case of a right to forfeit a lease for non-payment of rent.

The Ladup case can, therefore, be explained on the basis that relief against forfeiture for non-payment of rent falls within a class of its own so that the relevant statutory provisions were not to be treated as being exhaustive. Similarly, in Abbey National Building Society v Maybeech, ${ }^{55}$ Nicholls J held that, whilst no relief was available in respect of the failure to pay service charge contributions under s.146(4) of the Law of Property Act 1925 (which applied to other breaches as well as non-payment of rent) because there were no longer any landlord's proceedings during the pendency of which the claimant could apply for relief under that section, nevertheless, this did not preclude the court from exercising its equitable jurisdiction to grant relief from a failure to pay a specific sum of money. In both the Ladup and Maybeech cases, very clear grounds existed for affording relief to the chargee and mortgagee, respectively, due to the gross disparity in both cases between the possible ultimate loss to the landlord in having to wait a little longer for his rent arrears and the value of the leasehold security which the applicants for relief stood to lose.

In a second group of cases, however, an inherent equitable jurisdiction was denied in the face of the existence of a statutory jurisdiction covering the area in point. In Official Custodian for Charities $v$ Parway Estates Development Ltd $^{56}$ (decided on the same day as the Maybeech case), the question was whether the court had jurisdiction to grant equitable relief from the tenant's liquidation in circumstances where no such relief was available under s.146(10) of the Law of Property Act 1925 because the application for relief had not been made within one year of the tenant's liquidation as required by that section. The Court of Appeal held that, where the legislature had enacted particular legislation in a particular area (as, for example, in s.146(10) of the 1925 Act), the effect had to be given to it so that any wider equitable jurisdiction was thereby ousted. This reasoning was followed by Walton J in Smith v Metropolitan City Properties Ltd, ${ }^{57}$ a case involving the forfeiture of a lease for a tenant's breach of covenant to repair. Here, the tenant, against whom forfeiture proceedings had been completed (and the landlord had re-taken possession of the demised premises), sought to re-open

55 [1985] 1 Ch 190. See also, Cardigan Properties Ltd v Consolidated Property Investment Ltd [1991] 07 EG 132, where Mr P.J. Cox QC, sitting as a deputy judge of the High Court, was prepared to grant relief under equity's inherent jurisdiction which, in his view, s.146 of the Law of Property Act 1925 had not, in the absence of express words, completely ousted.

56 [1985] 1 Ch 151.

${ }^{57}$ (1986) 1 EGLR 52. 


\section{EQUITY'S JURISDICTION TO RELIEVE AGAINST FORFEITURE OF LEASES - AN HISTORICAL PERSPECTIVE}

the question of relief by invoking equity's inherent jurisdiction to grant relief. The essence of the tenant's argument was that, although the statutory jurisdiction under s.146(2) of the 1925 Act could not be relied on (as the landlords' proceedings had been completed), the court still had an equitable jurisdiction to grant relief in any circumstances in which the statutory jurisdiction was not available. Walton $\mathrm{J}$ held that such an argument was untenable on the authorities and "quite fantastic". ${ }^{58}$ In his view, the equitable jurisdiction to relieve for breach of covenant as between landlord and tenant (other than non-payment of rent) no longer existed.

The court's hostility to acknowledging the existence of inherent equitable relief within the compass of statutory provision is also highlighted in $\mathrm{Di}$ Palma $v$ Victoria Square Property $L t d,{ }^{59}$ where the tenant sought equitable relief in the High Court, having failed to pay arrears of rent in due time in compliance with a court order made pursuant to s.138 of the County Courts Act 1984. The Court of Appeal held that a tenant sued in the county court for non-payment of rent could only seek relief from forfeiture under the provisions of s.138 of the 1984 Act and that the words "barred from all relief" contained in s.138(7) meant he was barred from obtaining all relief whatsoever, including relief that might be obtained other than under s.38, namely, in the High Court. Although the actual decision has been somewhat tempered since the amendment of $\mathrm{s} .138$ by virtue of $\mathrm{s} .55$ of the Administration of Justice Act 1985, the decision illustrates the modern trend of the case law to rule out the possibility of equitable relief in the face of statutory intervention.

This trend is, perhaps, most vividly shown in Billson $v$ Residential Apartments Ltd, ${ }^{60}$ where the majority of the Court of Appeal held that the inherent jurisdiction as between landlord and tenant to relieve against forfeiture from a wilful breach of covenant (other than non-payment of rent) had been entirely extinguished by the provisions of s.146 of the Law of Property Act 1925. In the course of his judgment, Sir Nicholas BrowneWilkinson VC took the opportunity to examine the effect of the legislation on the three recognised heads of equity jurisdiction to relieve against forfeiture, namely, in the case of (a) fraud, accident or mistake (b) non-payment of rent or other specific sums of money and (c) wilful breach of covenant other than non-payment of rent where adequate compensation could be made for the breach. Under (a), relief could still be granted in an appropriate case even

\footnotetext{
${ }^{58}$ Ibid, 53.

${ }^{59}$ [1986] Ch 150.

${ }^{60}$ [1991] 3 All ER 265.
} 
where the fraud, accident or mistake arose in the context of a lease. On this point, the Vice-Chancellor observed: ${ }^{61}$

"In my judgment, the general equitable jurisdiction to relieve from the consequences of fraud, accident or mistake has never been affected by the statutory provisions and is not affected by section 146 . Say a landlord was by fraud to procure the tenant to commit a breach of covenant and then forfeited the lease and obtained possession. Can it be doubted that the court would relieve against the forfeiture on the grounds of fraud even though the statutory jurisdiction to grant relief was no longer exercisable?”

Under (b), the Vice-Chancellor concluded that the equitable jurisdiction remained intact and that the relevant legislation (which was largely procedural) merely modified and limited equity's power to grant relief in certain respects, particularly in relation to time-limits. Moreover, the inherent jurisdiction to relieve without time-limit continued to apply in cases involving a forfeiture by peaceable re-entry. Under (c), following a brief review of the earlier case law referred to earlier, ${ }^{62}$ the Vice-Chancellor concluded that the equitable jurisdiction to relieve from wilful breaches of covenant (other than on-payment of rent), which had been resurrected retrospectively by the House of Lords in the Shiloh case, had been extinguished in the landlord and tenant context by reason of Parliament having legislated comprehensively in that field.

\section{CONCLUSION}

From earliest times, equity recognised that it had jurisdiction to relieve against forfeiture where the object of the forfeiture clause was to secure payment of a definite sum of money. Accordingly, the Court of Chancery allowed a tenant to keep his lease provided that he paid the arrears of rent and the landlord's costs and expenses by a specified time. This equitable jurisdiction remains intact to this day subject only to various statutory provisions which have merely modified equity's power to grant relief in certain procedural respects. Whilst these provisions differ as between High Court and county court, the nature of relief in both jurisdictions continues to

${ }^{61}$ Ibid, 282.

62 Notably, Official Custodian for Charities v Parway Estates Developments Ltd [1985] Ch 151; Abbey National Building Society v Maybeech [1985] Ch 190 and Smith v Metropolitan City Properties Ltd (1986) 1 EGLR 52. 
be rooted in equity's inherent power to relieve against forfeiture for nonpayment of rent.

Whilst equity's jurisdiction to grant relief against forfeiture for nonpayment of rent remains extensive, its jurisdiction to grant relief in cases involving other breaches of covenant has had a chequered history. This is because, historically, the underlying principle governing relief was whether the landlord could be adequately compensated for his loss occasioned by the tenant's breach. Thus, whilst there was no difficulty in compensating a landlord for a tenant's failure to pay rent by simply permitting the tenant to tender late payment with interest and costs, other breaches of covenant did not readily permit the placing of the landlord in the same position he would have been if no breach had occurred. Coupled with this inherent difficulty was the Court of Chancery's acceptance of the principle that equity would not relieve against a wilful breach of covenant other than one involving the non-payment of a specific sum of money. The result, as we have seen, was the emergence of only a limited equitable jurisdiction to relieve from forfeiture restricted essentially to two specific heads of relief, namely, (a) where the right to forfeit was inserted by way of security for the payment of specific sum of money (such as rent) and (b) where the breach had been occasioned by fraud, accident, mistake or surprise.

The foregoing remained the position until the decision in Shiloh in which the House of Lords redefined the scope of equity's jurisdiction in more expansive terms so that the courts now retain the right, in appropriate circumstances, to relieve against forfeiture for breach of covenant or condition where the primary object of the bargain is to secure a stated result which can effectively be attained when the matter comes before the court and where the forfeiture provision is added by way of security for the production of that result. A modern example of the application of this principle is to be found in the recent case of Cukurova Finance International Ltd $v$ Alfa Telecom Turkey $L t d^{63}$ where the Privy Council held, by a majority, that it had a discretion, in exceptional circumstances, to grant equitable relief from forfeiture to a company on the basis that account should be taken of the fact that, although the company had defaulted on a facility agreement resulting in an appropriation of that security, it would be inequitable to ignore the circumstances of a subsequent offer of repayment under the agreement.

Although this resurrected jurisdiction remains intact in a general sense, it has now been overtaken in the landlord and tenant context by virtue of the provisions of s.146 of the Law of Property Act 1925. The upshot of this is that relief against forfeiture in respect of breaches of covenant or condition other than non-payment of rent is now governed exclusively by statute in the

63 [2013] UKPC 20. 
landlord and tenant field, except in cases where there is some element of fraud, accident, surprise or mistake ${ }^{64}$ or in circumstances where the statutory code does not apply. ${ }^{65}$

The retention of this inherent (albeit now limited) equitable power to grant relief from forfeiture of leases outside the statutory jurisdiction remains significant. The function of the common law has been to establish rules to govern the generality of cases and to promote certainty in our law. At the heart of equity is the notion that the requirement of certainty in decisionmaking needs to be tempered by the need for judicial discretion to achieve fairness in individual cases and to restrain the exercise of legal rights in order to ensure justice between the parties. In this sense, the common law and equity remain distinct but mutually dependent aspects of English law. Equity's function, in particular, is to regulate and supplement the common law by preventing inequitable or unconscionable results - a function that is no better evidenced, it is submitted, than in the evolution of equity's ability to prevent the unconscionable exercise of a landlord's right to forfeit a lease.

${ }^{64}$ See, for example, Barrow $v$ Isaacs [1891] 1 QB 417.

65 See, Shiloh Spinners Ltd $v$ Harding [1973] AC 691, (where the relationship of landlord and tenant did not exist); Ladup Ltd v Williams \& Glyn's Bank plc [1985] 1 WLR 851, (where relief was granted to an equitable chargee) and Abbey National Building Society $v$ Maybeech [1985] 1 Ch 190, (where relief was afforded to a mortgagee). 